ELORE (ISSN 1456-3010), vol. $16-1 / 2009$.

Julkaisija: Suomen Kansantietouden Tutkijain Seura ry.

[http://www.elore.fi/arkisto/1_09/heinonen_01_09.pdf]

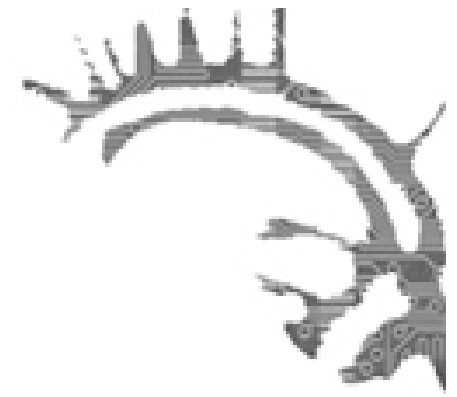

\title{
AJANKOHTAISTA:
}

\section{KALEVAlaisen RUNON TUTKIMUKSEN METODOLOGIAA}

\section{Kalevalaisen runouden tutkimuksen metodiseminaari Turun yliopistossa}

29.-30.1.2009

\section{$\underline{\text { Kati Heinonen ja Tuomas Hovi }}$}

Kalevala-instituutti, Kulttuuristen tulkintojen tutkijakoulu ja Kalevalaseura järjestivät Turussa tammikuun lopussa kaksipäiväisen kalevalamittaisen runon tutkimuksen metodologiaan keskittyneen seminaarin. Luentosarja-ajatuksen ja seminaarin taustalla on suunnitelma koota yhdeksi kirjaksi viime vuosina esitettyjä runontutkimuksen metodologisia avauksia ja näkemyksiä. Seminaarin toisena päivänä järjestettiin myös tutkijakoululaisten papereita käsitellyt työpaja vilkkaan keskustelun merkeissä. Tässä kirjoituksessa Kati Heinonen kertoo seminaarin ensimmäisestä ja Tuomas Hovi toisesta päivästä.

\section{AnalyytTisia tasoja}

Seminaarin avasi Pekka Hakamies (Turun yliopisto) esittelemällä ja vertailemalla John Miles Foleyn (1995) ja Matti Kuusen (erityisesti 1994) käsityksiä suullisesta runoudesta. Kuusen myöhäistuotannossa on joitain - usein ilmaan jääviä - ajatuksia runokielestä, jotka lähestyvät Foleyn sanavoiman ja rekisterin käsitteitä. Hänen tiedonintressinsä pysyi kuitenkin runojen synnyn ja leviämisen kysymyksissä.

Senni Timonen (Suomalaisen Kirjallisuuden Seura) aloitti pohtimalla lyriikan käsitteen ongelmallisuutta suullisen runouden tutkimuksessa. Käsitteen lähtökohta on kirjallisen runon tutkimuksessa, vaikka taustalla onkin antiikin Kreikan lyyran säestyksellä esitetty runous. Lyriikan tai tunnelmarunouden lajin keskeissisällöksi on hahmotettu laulullisuutta, subjektiivisuutta, tunteita, rytmiä, sointuvuutta ja kuvalli- 


\section{Kalevalaisen Runon tutKimukSen metodologiaA}

suutta sekä usein suppeaa ja jäntevää muotoa. Jos tarkastellaan, miten kalevalamittaisen runon laulajat ovat nimenneet omat laulunsa, huomataan kuitenkin, että käsite ei toimi: meidän lyriikaksi nimeämämme laji hajoaa. Laulajien mielessä lyriikaksi kutsumamme laji esiintyy miltei missä lajissa hyvänsä, epiikasta häälauluihin ja loitsuihin. Timonen esitteli esimerkkejä sekä klassiset lyriikan määritelmät täyttävistä, jäntevistä ja lyhyistä pohjoiskarjalaisista runoista että pidemmistä lyyristen teemojen ketjuista.

Pitkien, monia teemoja yhdistelevien lyyristen runojen ketjuuntumisen estetiikkoja tai logiikkoja ei ole juuri tutkittu. Timosen esimerkeissä esiin nousi useampia mahdollisuuksia. Joskus näyttää siltä, että yhteydet teemojen välillä ovat lähinnä assosiatiivisia: tietyt sanat ja ajatukset johtavat teemasta toiseen. Toisaalta pitkä ketju voi edetä myös vaikkapa runon minän elämänkulkua kuvaten. Joskus on kerääjän kontekstimainintojen tai matkakertomusten kuvasten perusteella mahdollista rinnastaa myös runon minä ja runon laulajan henkilö. Lyyrisissä ketjuissa saattaa olla sekä laajoille maantieteellisille alueille yhteisiä, suhteellisen kiinteitä teemoja, harvinaisempia tai suppeammalla alalla esiintyviä jaksoja että laulajan perinteisistä teemoista muokkaamia persoonallisia kehitelmiä. Ominaista Timosen tutkimusotteelle on liikkuminen runouden mikro- ja makrotasojen välillä. Yksittäisiä runoja tarkastellaan sekä tiettyyn hetkeen tai laulajaan sidoksissa olevina että suhteessa runoston kokonaisuuteen.

Lotte Tarkka (Helsingin yliopisto) kertoi ottaneensa seminaarin perusajatuksen opetuskäyttöönkin soveltuvan kirjan pohjustamisesta tosissaan. Hän lähti kartoittamaan intertekstuaalisuuden käsitettä eri tutkijoilla ja sen käyttömahdollisuuksia kalevalamittaisen runon tulkinnassa. Metodisesti kyseessä on tekstin tulkintatapa, jossa merkityksen katsotaan syntyvän tekstin ja sitä ympäröivien tekstien vuorovaikutuksessa. Kalevalamittaisen runon kohdalla kyse on tietenkin lauluista tai puhutuista runoista, jotka tosin ovat nykytutkijalle käytettävissä lähinnä kirjoitettuina teksteinä. Tarkan edustamassa lukutavassa olennaista on aineiston rajaaminen ajallisesti ja paikallisesti niin, että runojen voi olettaa edustavan yhden puheyhteisön käytössä olleita keinoja. Tulkinta ei kuitenkaan "pysähdy lähteen löytymiseen, vaan alkaa toiston havainnosta ja merkityksellisen suhteen oletuksesta." Keskeistä on ajatus toistosta ja tunnistamisesta, mutta jokainen esiintymä - jokainen esitys - on silti tulkittavissa autenttisena.

Lauri Harvilahden (SKS) teemana oli "Kova koulu käyäkseni. Opettavainen tarina Suomen Kansan Vanhojen Runojen tietokoneanalyysin varhaisvaiheista." Kaikki alkoi italialaisen tietokonelingvistin professori isä Roberto Buzan astellessa musta lierihattu päässään Suomalaisen Kirjallisuuden Seuran portaita vuonna 1984 ajatuksenaan Kalevalan runojen tallentaminen tietokoneelle. Hanke vaihtui inkeriläisten kansanrunojen korpuksen luomiseksi. Harvilahden mukaan 485 runon koodaamisessa kului valmistelujen ja kokeilujen jälkeen loppujen lopuksi kolme kuukautta, mutta analyysi, tulkinta ja väitöskirjan kirjoittaminen vei seitsemän vuotta. Tähän voi verrata Suomen Kansan Vanhojen Runojen (89 250 runoa) digitointiprosessia, jonka Arvo Krikman ja työryhmä hoitivat Tartossa uudemmalla teknologialla kahdessa vuodessa (1999-2000).

Ensimmäisen päivän jälkeen mielessä kiersi runsaasti ajatuksia siitä, kuinka monella tavalla tutkimusaineistoa voi koota ja käsitellä ja kuinka monella analyyttisella tasolla yhdenkin tutkimuksen piirissä voi liikkua. 


\section{Kati HeINONEN JA TUOMAS Hovi}

\section{NÄKÖKULMIEN KIRJOA}

Kalevalaisen runouden tutkimuksen metodiseminaarin toinen päivä alkoi Kati Heinosen (HY, SKS) esitelmällä "Esitysten välisiä suhteita", joka pohjautui hänen tulevan väitöskirjatyönsä aineistoon ja tutkimukseen. Heinonen esitteli omaa tutkimustaan esitysten välisistä suhteista länsi-inkeriläisissä kalevalamittaisen runon laulukulttuureissa. Hän käsitteli aihettaan muun muassa runon laulullisuuden ja esityksellisyyden sekä laulamisen rakenteiden, kontekstin ja tapojen kautta. Keskeisiä metodisia kehyksiä Heinonen on lainannut folkloristiikan lisäksi metriikan ja musiikintutkimuksen piiristä. Heinonen tutkii aihettaan kolmen osittain päällekkäisen tai limittäisen näkökulman kautta, laulun rakenteellisten piirteiden, laulamisen tapojen kuvausten ja seremoniallisten laulutilanteiden näkökulmasta. Heinonen havainnollisti esitystään sekä arkistomateriaalina kuultuna lauluesityksenä että laulamalla osia runoista itse. Esitelmän jälkeen esitetyt kysymykset ja kommentit käsittelivät sekä esitelmässä mainittujen termien ja käsitteiden tarkoitusta että sitä, tiesivätkö laulujen esittäjät tiettyjen lauluissa käytettyjen refrengisanojen merkityksiä ja voiko niistä edes tehdä tulkintoja.

Lyhyen kahvitauon jälkeen seminaari jatkui Satu Apon (HY) esitelmällä Sammon ryöstöstä narratiivisen analyysin kohteena. Apo tutkii millä tavoin kolme suomalaisen eeppisen runonkerronnan mestaria, Arhippa Perttunen, Ontrei Malinen ja Simana Sissonen kertoivat Sammon ryöstöstä ja miten Elias Lönnrot rakensi niiden pohjalta Kalevalaan oman versionsa runosta. Erittäin mielenkiintoinen oli Apon esittämä käsitys siitä, että Lönnrot olisi lisännyt tarkoituksella tuonpuoleisuutta ja runojen mytologisuutta saadakseen Kalevalan muistuttamaan enemmän homeerista eeposta. Toinen mielenkiintoinen asia, johon hän kiinnitti huomiota, oli Suomisanan käyttö Sammon ryöstön lopussa esiintyvässä rukouksessa. Kyseessä oli Apon mukaan joko Ontrei Malisen kohteliaisuuttaan käyttämä termi tai Lönnrotin tekemä, Kalevalan isänmaallisuutta korostava lisäys. Hän mainitsi myös, ettei ole ensimmäinen joka tähän on kiinnittänyt huomiota. Ensimmäisenä asian otti Apon mukaan esille kirjallisuudentutkija Kai Laitinen. Esitelmän jälkeen käydyssä keskustelussa mainittiin erityisen kiinnostavana tutkimuskohteena paralleelien etsiminen kalevalaisen runouden ja Odysseian välillä.

Seminaarin viimeisen esitelmän piti Elina Rahimova (HY). Hänen esitelmänsä aiheena oli kalevalamittaisen runouden vertauksien kartoittaminen Venäjän folkloristiikan etnopoeettisesta lähestymistavasta käsin. Rahimovan esitelmän alku liittyi venäläisen epiikantutkimuksen historiaan. Tarkemmin hän toi esille venäläisistä folkloristeista ja epiikantutkijoista Boris Putilovin ja Viktor Gatsakin. Erityisesti Rahimova esitteli Gatsakin käyttämää käsitettä etnopoeettinen konstantti, joka viittaa runoperinteessä ilmeneviin formulamaisiin pysyviin elementteihin. Näiden elementtien tutkiminen voi Rahimovan mukaan selvittää kalevalaisen runouden maailmaa nykyistä paremmin ja laajemmin. Mielenkiintoista Rahimovan esitelmässä oli myös Venäjän sivistyneistön piirissä hänen mukaansa vallitseva käsitys siperialaisen eeppisen runouden primitiivisyydestä ja alemmuudesta verrattuna slaavilaiseen venäläiseen perinteeseen. On mielenkiintoista, että eeppisen siperialaisen runouden tutkimukseen kohdistuu niin selviä nationalistisen suurvaltapolitiikan äänenpainoja ja näkemyksiä. 
Rahimovan esitelmän jälkeen Turun yliopiston folkloristiikan professori Pekka Hakamies esitti seminaarin lopuksi kiitokset osallistujille. Seminaari osoitti että kalevalaisen runouden tutkimus on tällä hetkellä erittäin elävää ja että kiinnostus aiheeseen on laajaa. Onnistunut seminaari herätti sekä seminaarin osallistujissa että sen järjestäjissä toiveita vastaavan seminaarin järjestämisestä tulevaisuudessa useamminkin.

\section{KirJallisuUs}

FOLEY, JOHN MILES 1995: The Singer of the Tales in Performance. Bloomington and Indianapolis: Indiana University Press.

KUUSI, MATTI 1994: Questions of Kalevala Metre: What exactly did Kalevala language signify to its users? - Siikala, Anna-Leena \& Vakimo, Sinikka (toim.): Songs beyond the Kalevala. Transformations of Oral Poetry. Helsinki: SKS.

Filosofian maisteri Kati Heinonen on jatko-opiskelija Helsingin yliopiston folkloristiikan oppiaineessa.

Filosofian maisteri Tuomas Hovi on jatko-opiskelija Turun yliopiston folkloristiikan oppiaineessa. 